2015

\title{
Christian Higher Education at the Start of the 21st Century: A Review Essay
}

David Johnstone

George Fox University, djohnsto@georgefox.edu

Follow this and additional works at: http://digitalcommons.georgefox.edu/student_life_works

\section{Recommended Citation}

Johnstone, David, "Christian Higher Education at the Start of the 21st Century: A Review Essay" (2015). Staff Publications - Student Life. Paper 25.

http://digitalcommons.georgefox.edu/student_life_works/25 inclusion in Staff Publications - Student Life by an authorized administrator of Digital Commons @ George Fox University. For more information, please contact arolfe@georgefox.edu. 


\title{
Christian Higher Education at the Start of the 21st Century: A Review Essay
}

\author{
David M. Johnstone \\ George Fox University, Newberg, Oregon, USA
}

Dockery, David S. (2012). Faith and learning: A handbook for Christian higher education. Nashville, TN: B\&H Academic. ISBN 978-1-4336-7311-5, 548 pages.

190 Hawthorne, John W. (2014). A first step into a much larger world: The Christian university and beyond. Eugene, OR: Wipf \& Stock. ISBN 978-1-62032-947-4, 163 pages.

Ostrander, Rick. Reconsidering college: Christian higher education for working adults. Abilene, TX: Abilene Christian University. ISBN 978-0-89112-398-9, 81 pages.

Every few years, evangelical scholars publish volumes addressing the nature of how their faith interacts with their academic discipline. While it would seem to be a task that does not need to be repeated, each new project is distinctive to the context in which it is written. Our world is different from 10 years ago, contributing to changes regarding how the conversation looks and develops. Some material is timeless, while other information changes. Currently, underlying the faith and discipline conversation is the utilitarian response that asks, "What makes a Christian college so special?" The implication is that one could gain an education at less cost in other places than a Christian college. The three volumes being reviewed, each in its distinctive way, seek to address the distinctive nature and value of Christian higher education.

\section{RECONSIDERING COLLEGE: CHRISTIAN HIGHER EDUCATION FOR WORKING ADULTS}

Rick Ostrander, the author of Reconsidering College: Christian Higher Education for Working Adults, is the current provost and chief academic officer at Cornerstone University in Grand

Address correspondence to David M. Johnstone, Associate Dean of Students, George Fox University, 414 N. Meridian St., Newberg, OR 97132. E-mail: djohnsto@georgefox.edu 
Rapids, Michigan. Ostrander directed his volume to the nontraditional student-those who have been out of education for a time. These students typically are seeking to improve themselves and their vocational options, so they are returning to college or university. Ostrander himself was married at 21 and decided to work while his wife went to college. After she completed her master's degree, Ostrander pursued his own education. His family expanded, and so did the complexities he faced as a nontraditional student.

Ostrander explored the distinctive nature of pursuing higher education for the follower of Jesus, including the value of doing so at a faith-based or distinctly Christian institution. He presented a theological reflection on why work has a place in the life of a believer. He also developed the idea of work as an act of reverence and worship, which implies the need to pursue tasks and vocation with diligence and excellence. Education helps define that excellence. Education-and particularly Christian higher education-broadens the understanding and awe for how God has shaped and interacts with the world.

Ostrander's ideas were simple but not simplistic; he could have developed them a little more and still kept the volume short, which might have been a goal. Descriptions of his teaching that illustrated the theological development within the book were fascinating, hinting at a creativity that was restrained in the book; I wanted more such engaging and intriguing illustrations.

The strength of his book is contained in Ostrander's concluding chapter on integrating one's faith with what is being learned. He stated, "The integration of faith and learning means relating one's faith to an academic discipline" (p. 67). He further noted that faith and learning integration means more than a professor "praying before a class" (p. 68) or inserting "religious material" (p. 69) into the class content. The aim of integration is multifold. At the simplest level, it "motivates us to learn. . . the subject of study as a way to grow in our relationship with God" (p. 69). Further, an integration of faith into a discipline informs the dialogue about what is known and what can or cannot be known. According to Ostrander, the "final way that Christian universities integrate faith and learning" (p. 75) is to explore the ethical and applied aspect of faith to different disciplines. This is where the application of the knowledge developed in a discipline needs to be informed by the realities of a worldview. The implications of a Christian worldview are broad and cross many academic disciplines. This simple integration model, which represents a strength of the book, provides a good case for considering Christian higher education.

\section{FIRST STEPS INTO A MUCH LARGER WORLD: THE CHRISTIAN UNIVERSITY AND BEYOND}

John Hawthorne, author of First Steps Into a Much Larger World: The Christian University and Beyond, is a professor of sociology at Spring Arbor University in Michigan. He describes the purpose of his book as "[seeking] to establish a unique role for Christian higher education in this post-modern world" (p. 8). In contrast to Ostrander's orientation toward adult students, Hawthorne's book presents the depth and breadth of Christian liberal arts education, focusing on prospective or entering traditional-age students. He challenges these students to think Christianly and to discern not only the distinctive, but also the transformative, nature of Christian higher education.

Although Hawthorne's stated intention is to write for entering students, his reflections have the potential of reaching a much broader audience. Hawthorne notes that students progressing 
through their college experience often move into a routine oriented simply toward completing graduation requirements, yet the potential of Christian higher education offers much more. Hawthorne acknowledges that transitioning into the college as first-year students requires work, adding that "Those who pretend they know all the ropes (because of siblings at the school or past contacts) truly are pretending" (p. 3).

Despite the challenges, new students should never consider themselves to be alone and isolated. And while they may focus excessively only on what needs to be accomplished, Hawthorne challenges readers to avoid limiting themselves but rather to take advantage of the full range of opportunities within the university setting. In referring to topics that often challenge faith, Hawthorne queries: "How can one be a good Christian and seriously consider such topics?" (p. 8). In response, he asserts that it is possible to be a faithful believer and a student who seeks understanding with integrity.

Hawthorne offers a disconcerting observation about the nature of our current culture: "The preferred strategy seems to be to hold to one's position regardless of its logical conclusions or difficulties in implementation" (p. 8). He suggests that this approach stems from fear of the ambiguous, and encourages students to set aside their discomfort and explore the multitude of possibilities found within a university and college. While "it is not the task of faculty and staff to tell students how to solve their quest for meaning" (p. 11), students will encounter tremendous support within the academic setting. That support comes from staff, faculty, and peers.

In light of all this, Hawthorne asked a foundational question: "How can you build connections with others that protect you from the excesses of your new-found freedoms?" (p. 27). With this rhetorical question, he notes, "The peer group with whom you bond and those with whom you form bridges can influence your behavior for good or ill" (p. 27). Unexpectedly, Hawthorne used the Wizard of $\mathrm{Oz}$ as a paradigm through which to look at a student's college experience. Each of the main characters is a type that students (Dorothy) encounter in their experience. The Scarecrow is a metaphor for faculty, the Tin Man for student life, and the Lion for staff and administration. All provide support in different ways for the student. A student's connections are the foundation from which personal faith can flourish or founder.

From his perspective as a faculty member, Hawthorne summarizes the importance of students embracing the goal of integration: "At the end of the day, my classes have to mean something to you personally. If not, we've just gone through the boring motions of racking up three more credits" (p. 29). Similarly, Hawthorne's challenge to students is summarized:

[If your] view of the world gains a little more clarity, if you understand your roommate or your parents just a little better, if you're able to talk calmly about major political choices-in short, if you are a better person than you were before the course started — then we've been part of something remarkable. (p. 29)

Thus, at the core of Hawthorne's reflections is the challenge to students to integrate their faith with their academic pursuits and endeavors. Faculty members at a Christian university want their classes to have some significance - they long for them to mean something.

Using nutrition as a metaphor, Hawthorne noted, "Too many students approach the array of required classes as a set of individual meals to be consumed rather than a long-term commitment to a healthy diet" (p. 135). Others tackle their academic career as a buffet, only choosing what they like and want. Overall, Hawthorne offers a reassuring perspective to students who may be unsure about what influence academic pursuits will have on their faith: "It may seem as if you are 
'losing your faith' but it is more likely that you are, perhaps for the first time, thinking seriously about what you believe" (p. 104). With kindness and respect for his student audience, Hawthorne thus offers assurance that academic pursuit is beneficial to the process of maturing in faith.

Hawthorne encouraged students to view all their interactions as part of their education. The ability to process and imagine with peers and discern how disciplines might inform one another is an important component of their education. The defining characteristic of Christian higher education is summarized by Hawthorne: "The kingdom of God is the central theme of the Christian university. It is our way of being. We aren't simply preparing for the Kingdom; we are experiencing it on a daily basis. In so doing, we're helping establish it in the broader society" (p. 134). Thus, faith and learning are to be integrated in ways that have implications during the college years and far beyond.

\section{FAITH AND LEARNING: A HANDBOOK FOR CHRISTIAN HIGHER EDUCATION}

David Dockery, the president of Trinity International University, is the editor for Faith and Learning: A Handbook for Christian Higher Education. Dockery previously served as president of Union University, where he gathered scholars from a myriad of disciplines to compile this handbook. Twenty-one of the contributors have direct ties to Union University, but the group represents expertise in a broad spectrum of higher education roles and disciplines. Drawing from his theological background and his academic network, Dockery's stated intention was to provide a resource for Christian college, university, and seminary students as they engage with the implications of faith for their academic disciplines and vocations. He affirmed that being a thoughtful Christian student "will shape the way we think about schools, businesses, health care agencies, governments, social structures, recreation, and, yes, our homes and churches" (p. 4). Dockery built his collection of essays on Augustine's assertion that "all truth has its source in God, composing a single universe of knowledge" (p. 5).

In addition to providing this foundational perspective on the disciplines and vocation, Dockery hinted at a secondary agenda: "We will never be prepared to engage these matters if we adopt the anti-intellectualism sometimes found in the churches" (p. 6). This comment suggested a concern for intelligent and articulate intersection between faith and academia. Dockery also noted, "Christian thinking calls for us to bring the Christian faith to bear upon our study and our research within our various disciplines" (p. 6). While emphasizing the critical nature of faith informing studies, Dockery acknowledged: "Sometimes the issues with which we wrestle are filled with ambiguities. Even with the help of Scripture and Christian tradition, we recognize that we are finite humans who see through a glass darkly" (p. 7).

The chapter authors addressed a myriad of disciplines and subjects in Dockery's handbook. These authors, all experts in their fields, trace how faith has historically intersected with the disciplines being addressed, how those disciplines are currently influencing or being affected by faith, and which areas can be more fully informed by faith in the future.

Dockery's handbook format provides a general theological focus that is foundational for Christian higher education. Elsewhere, many have written about how the humanities and social sciences are influenced by faith. One of the values of this volume is the special attention given to the STEM (science, technology, engineering, and medicine) fields, which traditionally have represented challenges for teachers and scholars seeking to integrate faith. 
A sample of how these areas are discussed can be found in Mark Bolyard's chapter titled "A Christian in the Sciences," in which Bolyard traced historical roots to illustrate how Christians "were heavily involved with the development of science" (p. 346). Bolyard also discussed the current challenge of the origins conversation, offering multiple perspectives on evolution and their implications for faithful believers. He then demonstrated further challenges encountered by the biological sciences in areas as diverse as bioethics and nanotechnology, maintaining humility throughout his reflections. Bolyard affirmed, "The foundation of the Christian intellectual tradition in the sciences involves an effort on the part of the scientist to think actively about the faith/science relationship" (p. 348). An important point that, Bolyard argues, often becomes lost in the attempt to discern meaning derived from observation is that "in the practice of science, scientists make a distinction between data and the meaning of the data" (p. 354).

Pharmaceutical sciences professor Blake Watkins provided reflections on how faith can inform study and practice related to the health fields. Watkins noted, "A distinct advantage. . . Christian university campuses have over secular universities is the ability to apply a truly holistic approach to patient care, not in a coercive but rather a grace-filled manner" (p. 410). This is at the heart of modern medicine, the commitment to care for the patient and to cure the disease. Sometimes these objectives are partners in the same direction, at other times they are in tension. Watkins observed that faith-filled medicine is based on the premise that all humans are made in the image of God and, therefore, are inherently valuable. . . providing the impetus for caring for the patient. This perspective can become lost in the desire to produce a cure, sometimes to the neglect of the patient care. Watkins maintains the holistic nature of faith melding with medicine in responding to the care and cure of tensions. In summary, Watkins affirms, "our role. . . is to seek to redeem our present time in history" (p. 410), identifying this affirmation as the ultimate goal of faith-filled health care.

The final section this handbook addresses how faith is applied to the general pedagogical (curricular and cocurricular) work of the university. This chapter by Kimberly Thornbury contains the observation that the "Christian intellectual ... tradition knows no boundaries" (p. 500). In an academic setting, this tradition and faith "cares just as much about how you pursue life together on campus as it does what happens in the classroom" (p. 500). Thornbury also stated, "Christianity opposed the notion that head knowledge trumps practical living in the real world" (p. 500). One of the essential goals of Christian higher education, although not always stated, is that all elements of a campus community, whether the classroom, residence hall, or gymnasium, are significant. All of these settings and experiences "take faith and learning out of the realm of the abstract and into the world of real daily choices" (p. 508). The campus community becomes a laboratory where faith and learning are brought together and students are given the challenge and freedom to integrate their learning into their lives.

The three volumes covered in this review are very different in range, thesis, and audience. One (Ostrander) argues for the significance of a faith-filled education, with a focus on adult students. Another (Hawthorne) provides a broad and deep foundation for a philosophy of Christian liberal arts, focused on traditional undergraduate students. The last (Dockery), with focused intent, presents how the different disciplines within a Christian university respond to the challenge of integrating faith with integrity and congruence. The common thread in all three books is the admonition to allow faith to permeate the depths of not only study but the content of the discipline. All three note that when faith does so, the implications and praxis of faith inform disciplines in a broad and deep way. 